\title{
Adoption System in Some States in the $E U$ and America
}

\author{
Silvia Timofti \\ Faculty of Economic Sciences and Public Administration, Law specialization from Suceava, Romania \\ Master in Administration and Formation of Human Resources in Organizations at "Stefan cel Mare" University of \\ Suceava, Romania, timoftisilvia@yahoo.com
}

\begin{abstract}
In this material we will highlight the distinct adoption elements of the world's states, such as the US, Germany, Great Britain, Italy, France. In order to really know the evolution of our adoption system, it is necessary to compare us with other states to see the differences and similarities between them. The favor for adoption is the favor for the child and for the adopter. The importance for adoption is the importance for the children and for adopter. Therefore, the best interest of the child must be the most important thing in the institution of adoption. The national laws of the world's states have different mechanisms for implementing the adoption procedure. These differences are given by family traditions, culture, habits, religious concepts, social and political context, and last but not least their history. There are states that do not admit adoption with a adopter of race, religion different from that of the child. With the development of the adoption system, borders have been opened, adopting between races, international adoptions or same-sex adoptions.
\end{abstract}

KEYWORDS: adoption, adopted child, adopter, child's best interest, adoption procedure

\section{Introduction}

Adoption in Europe has a recent history, while it was introduced in the USA in the middle of the nineteenth century. In 1851, the state of adoption was adopted in Massachusetts, inspired by English law. In the United Kingdom, adoption laws were adopted 75 years later. In Europe, the first forms of adoption were identified in the French Civil Code in 1804, which retained certain elements of the fact that adoption is a contract between the adopter and the adopter, it has effects on: the maintenance obligation, the name, the inheritance, etc. Some states require the adoption of adopters in that country during the process of international adoption, such as Spain, Greece. In other countries, only children with special needs, disabilities or more brothers can be adopted internationally.

As regards the selection and evaluation of adopters, certain social services are responsible in countries such as Denmark, Maureen Britannia, Irlanda, in other countries these responsibilities lie with the private organs involved in adoption. In Italy, the decision of evaluation/attestation of potential adopters rests with the court system of evolving social services. Consent to adoption can be considered from the age of 12 in Denmark and Netherlands, at 14 years in Germany.

It is listened to in Italy and the child carries less than 12 years of age depending on his / her discerning ability. Regarding people who can adopt. In Italy, they can admit married people for at least 3 years, and can also accept their own people. With respect to couples of same-sex couples in Great Britain, Netherlands is accepted, but in Austria, only one of the same-sex couple can be adopted by Germany. The Czech Republic, Denmark, Italy accepts married couples.

Individuals who are alone can adopt in the majority of the states listed above. In Ireland, the married person may adopt only with the consent of the other spouse, if they live separately in Germany, the married person can only accept one of the spouses is declared legally incapable of admitting to have under 21 years of age. The majority of the legal provisions on the admission process are significant. Stage on the child's fit with the adoptive family in several places: Italia, Great Britain, Germany. The child's shelter varies from 3 months in the UK, the Czech Republic six months in Irland and 3 years in Italy in the case of single people.

\section{Adoption in the USA and the European Union}

In the US, no institution can separate the rights and obligations of the family towards the child. In the last period, legislation has made it possible for other institutions to intervene in protecting and defending the rights and interests of the child, in addition to the family. At the beginning of the sec. It was the 
seventeenth if it was the admission institution. At that time legal procedures were not yet stable, there were not a number of social workers, nor were the criteria for the choice of potential adopters identified. During that period American society empowered the family with the obligation and responsibility to raise and educate the child. On November 19, 1997, former US President Bill Clinton signed The Adoption of the Family Act. That law has replaced the "foster care" children, by which it became the best solution for children in difficulty. Easy, easy adoption became a measure that allowed children to have a home. Since 1998, the US has begun accession to the Haga Convention on International Adoption. The conditions were:

1. The adoptive parent must be at least 10 years older than the adopter;

2. Can be adopted an unmarried minor child;

3. The child aged 12 years must consent to adoption;

4. Can adopt married / unmarried adults.

In New York, consent must be given to the natural parents, the person or the caretaker who holds the custody. The criteria for choosing an admittance team are:

5. Age;

6. Geografic area;

7. Marital status;

8. Level of education;

9. Religion.

There are many adoption done in California. The law allows the private admission to take place through an attorney. The lawyer is the intermediary between future parents and natal mother. In the past, it was difficult for a single copist to adopt a child, the consequences being the issues that they invite during the growth. Keeping the secret about adoption was a problem, but at the time of the matter it became necessary to make public information about adoption for medical and genetic reasons In Germany, the law on adoption is laid down in the Civil Code. For a child to be adopted in Germany, both the adoptive parents and the biological parents of the child must agree. In Germany, an adoption can only be brokered by specific organizations, such as child protection offices and accredited adoption agencies. In Germany, in principle, only married couples can adopt a child. In exceptional cases, a single person can adopt a child (Zanzu.de n.d.).

The German law claims that the adoptors are married. The child to be adopted must be 8 weeks old, as well as the adult and the majority, although it is morally justifiable. In order for a child to be admitted to Germany, a public notary must be filed and the lawful agreement between the child (for example, if he is over 14 years old) should be the legal representative of the child (if at least 14 years old) and the parents biological. In the case of a married person, the husband's consent is not required and his consent is consented to by a notarized act which is valid even though he is admitted by the judicial establishment. The request for admission is processed at an admission service or a youth office where the solicitor is domiciled or by a recognized professional (Lupașcu, 2005). The adoption procedure for a German child is very difficult, so many German citizens have turned their attention to other states to end their admission. In France, the number of international adoptions has increased 4-fold in 24 years, according to the law (Academia.edu 2019). Adoption in France was recognized before the revolution. General Assembly in 1791 issued a decree with the purpose of including in civil laws those referring to adoption.

France in 1905 joined the Haga Convention. Napoleon's code was the one to stall the conditions, effects, forms of adoption. With the adhesion of France to the Haga Convention, the institution of admission has moved from contract to judicial. The judge verifies that admission is in accordance with the law with well-grounded reasons, the child's best interests and fundamental rights are respected.

In France:

1. A child may be abstained from the age of 3 months to 15 years;

2. The child is entrusted with placement for a period of at least 6 months;

3. Children in the signatory countries of the Haga Convention; 
4. In France the adoption is baptized and is recognized after a judge pronounces adoption;

5. A couple wishing to adopte must be married for at least 2 years;

6 . The single person who wants to adopt must be at least 28 years of age;

7. Parents must be at least 15 years older than the child;

8. The process of international admission in France is slow and stretches over a period of several years.

In Italy, the local courts of minors are in charge of the judiciary, administrative and public services and administrative bodies. At the level of the justice ministry, a database of information on child abducts and potential abductors was organized.

In Italy:

1. The adoptable child must be under the age of 18 ;

2. Adoptive parents must be at least 18 years of age and not older than 45 years of age;

3. Age conditions are imposed for the child's condition similar to those of a normal family;

4. In Italy adopt of married couples of at least 3 years;

5. Couples who adopt must stay in Italy (in the context of international admission);

6. Wives that wish to admit shall submit the request of the juvenile court and their availability for admission;

7. The minor who has reached the age of 14 years must express his / her consent to adoption;

8. Admission to Italy 3 years and costing EUR 5,000 (2006);

9. The child is entrusted to parents for a period of 1 year;

10. The court will monitor the child's care through social welfare services. The evaluation was finalized in 120 days with the possibility of extension for further 120 days.

11. Adopted child is originally at the age of 25 years. Instability is the only way to authorize access to information;

12. Italia adhered to the Haga Convention in the year 1998 (Commissione per le Adozioni Internazionali 2019).

In Britain, this measure of child protection after the First World War was adopted. The main goal was not to create a family for a child, but to find a child for a family that is not a child. The main body in the adoption process are the agencies authorized for adoption. Authorized agencies are the voluntary companies that make part of the social services of the local authorities. At the decision-making level, the responsible structures are independent of the admissibility of the agency and the judicial instability.

In Great Britain:

1. I can do the people who have more than 21 years, married to be alone;

2. The age difference between the child and the admissions family must not be over 45;

3. Married couples must agree together;

4. Persons who wish to admit small children of one year are subject to a number of restrictive conditions on admission, one of which is aged between 26-35 years;

5. Very few children are admitted to Great Britain, and a statistic indicates that in the year 2005 some $40-50 \%$ of the children were adopted. The Government of the Kingdom of Great Britain has made a statement and a White Paper on Adoption, which includes proposals for England and Wales to support the increase in the number of admissions.

\section{Conclusions}

Starting from the premise that the family is the basis of society, I want to add that a family without children is a family without a future, it is a family without a past and without a present. His Majesty the child, as someone said, is the being that brings light and removes the darkness within a family. That is why everything related to the protection and promotion of the rights of the child must be taken by the state institutions in the most serious way possible, by involving them as actively as possible and by working together. Social changes have largely led to changes in the vision of adoption in many 
countries in the world, and this is encouraging (Avram 2001) because with the evolution of society, adoption of the child.

\section{References}

Academia. 2019. "Legea aplicabila filiatiei si adoptiei (The Law Applicable to Filiation and Adoption)." Available at https://www.academia.edu/9999851/Legea_aplicabila_filiatiei_si_adoptiei. Accessed on May 5, 2019.

Avram Marieta. 2001. Filiation. National and International Adoption. Bucharest: ALL BECK Publishing House

Commissione per le Adozioni Internazionali. 2019. Available at http://www.commissioneadozioni.it/. Accessed on May $5,2019$.

Lupaşcu Dan. 2005. Family Law. Bucharest: Rosetti Publishing House.

Zanzu.de. n.d. Available at https://www.zanzu.de/en/rights-and-law/your-rights/adoption/. Accessed on May 5, 2019. 